\title{
The Pattern of North Korea's Local Military Provocations
}

\author{
Sangbeom Yoo and Sangjin Kim
}

\begin{abstract}
In this article, the authors suggest a statistical analysis regarding the pattern of North Korea's local military provocations by using quantitative data. The outcomes of the logit model indicate that there are negative relationships between provocations and regime-building periods, the Cold War era, and GDP per capita (limited to internal factors), while demonstrating a positive relationship with post-purge periods. Contrary to the widespread perception that NK leaders tended to be cautious when committing local military provocations during the combined forces exercises of the Republic of Korea and the United States militaries, results show that there was no systematic relationship, while North Korea was less likely to initiate local provocations during the reduction of U.S. forces in Korea. These outcomes tell us that the provocations are mostly driven by internal causes rather than external stimuli, and that North Korean leaders are more likely to utilize provocations in order to demonstrate power when they are politically strong and may have an incentive to divert internal economic discontent when the country is economically weak.
\end{abstract}

Key Words: North Korean military provocations, diversionary war theory, quantitative approach, ROK-US combined military exercises

\footnotetext{
T ooking back on the history of North Korean (NK) military provocations since 1 the armistice in 1953, around 1,100 recorded cases have been observed thus far. For what purposes did the NK regime commit these provocations? Many experts have tried to answer this question by suggesting several explanations, such as diverting the people's dissatisfaction toward the NK regime, as a tool to build NK's regime security, as a method to escape international isolation and gain a negotiation advantage by building up tensions on the Korean Peninsula,

*Sangbeom Yoo(jsf4th@kndu.ac.kr) is an associate professor at Korea National Defense University (KNDU) and director of research planning at the Research Institute for National Security Affairs (RINSA). Since getting his doctorate at the State University of New York at Binghamton in 2012, he has been a faculty member in the Department of Security Policy at KNDU. His research interest includes conflict studies and U.S. foreign Policy.

**Sangjin Kim(wkrorhfnic79@naver.com) is currently serving at Korean Naval War College, and major in the Republic of Korea (ROK) Marine Corps.
}

The Korean Journal of International Studies Vol.15, No.1 (April 2017), 71-84 
and well as many other suggestions. However, since most research has paid more attention to individual case studies or comparative analysis of different provocation events (Gause 2015; Han 2012; Kim and Ji 2013; Kim 2001; Moon 2011; 2012), it has been difficult to generalize about the motivations of North Korea's military provocations (Yoo 2014). This project attempts the daunting task of finding a general pattern in North Korea's local provocations using a quantitative approach.

Before stepping into the main topic, it is necessary to recognize why this subject related to local military provocations is worthy of pursuit. First, the situation on the Korean Peninsula is very unique because the two Koreas have been divided for more than seventy years and are the only separated country in the world. There was a full-scale war between the two from 1950 to 1953 and, since signing an armistice, there has been a period of sustained hostilities along the de-militarized zone (DMZ). Under these severe conditions, low-level military provocations have a lot of utility both internally and externally for the NK leadership. Finding out when and why these kinds of provocations occur is desirable for a more comprehensively understanding North Korean motivations and decision-making.

Second, military provocations are both effective and durable. In reality, North Korea's nuclear weapons tests and long-range missile launches have huge potential to invite strong international pressure on the regime, meaning they can be very costly not only economically but also politically. In contrast, local provocations are relatively economical and sustainable over the long-term because they can be consistently utilized as a military and political option. For this reason, research focusing on local provocations also should pay attention to military usage at the strategic level.

Third, any local provocation clearly must be intentional and/or act as a signal to either the Republic of Korea (ROK) or the international community. There are two types of provocations, according to the Joint Chiefs of Staff (JCS) of the ROK: infiltrative provocations and local provocations. The former aims for not being discovered while the latter are potentially undertaken out in the open for both the provocation target and an international audience to witness. Local provocations are sometimes used as a tool to send some form of message to a negotiation partner, outside observer, or even a domestic audience. Therefore, determining the pattern and regularity of these cases is worth attempting for both policy and scholarly purposes.

There is a practical reason why the pattern should be investigated as well. On August 4, 2015, North Korea engaged in a land-mine provocation in the DMZ, causing two soldiers to be wounded. South Korea replied with anti- 
Pyongyang psychological warfare broadcasts through loudspeakers for the first time in 11 years (Joongang Daily 2016). This led to a dramatic rise in tensions on the Korean Peninsula. The interesting thing was the timing because it overlapped with the period of the annual ROK-U.S. military exercise 'UlchiFreedom Guardian' (UFG). There was the perception that North Korea had been avoiding military confrontations with the United States and, therefore, it was believed that the North would adopt a prudent stance during the period of these combined military exercises. Whether or not the land-mine incident was an anomaly should be clarified.

With this in mind, and seeking to find any regularities in NK military provocations, this paper is organized as follows: the next section provides a review of the literature, the third section discusses the research design used to explain the pattern of NK local military provocations, the fourth section analyses the results of the statistical models, and the concluding section offers policy options for a reduction in NK military provocations.

\section{LITERATURE REVIEW}

Earlier studies are numerous and show a considerable number of differing results. These studies can be divided into two groups: qualitative and quantitative. As for qualitative, many studies have focused on the cause, process, and results by specific case or by a comparison of several cases (Gause 2015; Han 2012; Kim and Ji 2013; Kim 2001; Moon 2011; 2012). This approach was used to search for a cause of, and correlation among, factors and provocations, which can be divided into domestic and foreign causes. Among internal factors, crises of political instability in North Korea, transitional periods, economic conditions, and purge periods were frequently chosen. Moon (2012) analyzed the cases of 1968 and 2010 with the purpose of finding the reason for the surging number of military provocations and argued that in both cases the primary motivation was to promote regime stability. These two periods coincided with the emergence of new heirs, during which there were incentives for the existing leaders to show their power or deter possible challenges to leadership successors. The work of Han (2012) was also a comparative study of local provocations between the Kim Jong-il and Kim Jong-un periods. According to Han, the military provocations of North Korea tended to increase during economic crises and regime successorbuilding periods. This argument basically is based on diversionary war theory, which suggests that military tools can be seen as useful for diverting domestic discontent when a leader or a ruling group is facing problems that cannot be 
easily resolved (Gent 2009; Levy 1989). For an interesting argument, Gause (2015) suggested a relationship between political tension and provocation, arguing that there were more military provocations observed during purge periods. This was based on the belief that North Korean leaders have a very strong incentive to show their power in order to secure their positions when potential or present challengers were determined.

Other scholars have focused on the utility of military provocation under North Korea's strategy toward South Korea (SK). Kim $(2014,30)$ argued that military provocations were based on "the cycling strategy [that] is the primary solution to defend the ancient regime without fundamental reforms," and that the strategy was embedded in the survival of the leadership. Therefore, Kim Jong-un was expected to be more combative than his predecessors.

There are also several external factors that correlate with the frequency of provocations. Kang (2010) drew attention to the effects of U.S. foreign policy by asserting that a hawkish policy normally promoted by presidents from the Republican Party induced more provocations, while a dovish one invited fewer. In a similar vein, Son (2012) found that the effects of SK government policy produced outcomes that were not very different from the effects produced by the hawkish policies of Republican presidential administrations. During the reign of conservative parties in South Korea, there were more instances of the usage of military tools than during opposition party rule. According to Son (2012), the combination of US and SK governments produced certain patterns such that Democratic Party and progressive party presidents of both countries sent dovish signals to a North Korea that elected to respond cooperatively, which caused the probability of military provocations to decrease.

On the other hand, quantitative studies have put more emphasis on finding the overall pattern of North Korea's provocations. Compared to qualitative approaches, there has not been a significant amount of research using quantitative approaches. Yoo (2014) seems to be the first to find a general pattern in NK military provocations by using quantitative data compiled by the United Nations Command of the Military Armistice Commission (UNCMAC). His research suggested that bad economic conditions and the period of NK's nuclear weapons program were positively related to the number of provocations, and he also mentioned that those outcomes were not conclusive because of the incompleteness of the data and the small number of observations.

During this project, Victor Cha, Na Young Lee, and Andy Lim at the Center for Strategic and Security Studies (CSIS) published a paper titled "DPRK Provocations and US-ROK Military Exercises," which dealt with issues very similar to those in our research. According to these authors, US-ROK exercises 
had a "null-effect" on NK provocations from 2005 to 2016 and, "the state of U.S.-North diplomatic relations before the exercise period (defined as 4-8 weeks prior) [wa]s actually a better indicator of whether North Korea w[ould] carry out any provocation during or after the exercises" (Cha, Lee and Lim 2016). Since their research focused on only one factor (US-ROK combined military exercises), our research expands on this to include a focus on multiple variables and a longer duration period for the purposes of analysis, which should be more beneficial to the goal of generalization. Though there have been several attempts to find general trends in North Korea's local military provocations, there has not been much research using statistical methods compared to the use of qualitative approaches. This paper aims to make a contribution to fill the gap between these two approaches by using a new data set.

\section{RESEARCH DESIGN}

\section{MODEL AND DEPENDANT VARIABLE}

This study examines whether internal and external factors of North Korea correlate with the occurrence of local provocations by using the following statistical model:

$$
M P_{i}=\alpha_{i}+\beta_{1}(\text { NK Internal Factors })_{i}+\beta_{2}(\text { NK External Factors })_{i}+\varepsilon_{i}
$$

The dependent variable of this model is the existence of military provocations (MP) committed by North Korea in any given month. Local military provocations are defined as "all aggressive military related behaviors with the purpose of achieving a certain goal towards the SK people and sovereignty in a certain area" (JCS 2014, 69). ${ }^{1}$ Compared to full scale war, these military provocations have a locality in terms of region and goal but were no different in terms of tools that were used because local provocations can occur in all dimensions from land, air, and sea to cyberspace. The data for provocations was collected in a monthly database through investigating the accumulated compilations offered by the ROK Department of Defense (JSC more specifically). Data was coded ' 1 ' if there was any military provocation in a certain month and 'o' otherwise.

\footnotetext{
${ }^{1}$ Examples of local military provocations committed by North Korea include the 'Axe Murder Incident' in 1976 in the Joint Security Area (JSA), which is considered a serious level of provocation, and crossing the Northern Limit Line (NLL) or Military Demarcation Line (MDL), which is viewed as a low-level provocation.
} 
There could be a debate regarding the feasibility of the dependent variable assuming each individual provocation should be treated equally and whether the existence of a provocation is an appropriate measurement for the research questions. There are two reasons for this assumption. The goal of this research is to find out the cause of North Korea's military provocations, not the effects or outcomes of certain military activities. This implies that what we have observed are outcomes of the provocations, which might include South Korea's reactions and other factors. This research is focused on the existence of provocations in a certain time period. The second reason is related to the first to some degree. Since the role of local provocations for the NK leadership is to achieve certain political goals or to enable circumstances with which North Korea would be able to take advantage at the negotiation table, provocations by themselves should be known to the SK public, or at least to SK decision-makers. Therefore, it is safe to assume that any provocation may have the potential to invite attention when it is successfully implemented. With these reasons in mind, for the dichotomous dependent variable-either 1 or o-logit regression is an appropriate method for analyzing this model. ${ }^{2}$

\section{INDEPENDENT VARIABLES}

Independent variables are largely divided into NK internal factors and external factors that can be related to local provocations. There are eleven variables, six of which are internal factors and five of which are associated with external ones. As a parameter of the internal factors of North Korea, Regime Instability is operationalized as the period of regime-building for each leader, the Purge and After Purge Period, Economic Conditions, Nuclear Tests, and Missile Tests are included as variables. As for the group of external factors, the ROKUS Combined Exercise Period, Reduction of US Forces in Korea, the Cold War Period, SK Elections, and Partisanship of US and SK Presidents were chosen.

As for the Regime Instability factor expressed as a period of regime-building, for the Kim Il-sung era it was the period from the end of the Korean War in July 1953 to the First Conference of the Workers' Party of Korea in March 1958. ${ }^{3}$ In

\footnotetext{
${ }^{2}$ To check the robustness of this model, the authors relax the assumption of the equality of each provocation by changing the dependent variable from the existence to the frequency of military provocations and run the OLS regression model. The results are not significantly different from the original model.

${ }^{3}$ There are different opinions about when Kim Il-sung had solidified his position as the supreme leader of North Korea. The first is that Kim had established his leadership status by The Third Congress of the NK Workers' Party in April 1956. Another is that Kim secured his leadership status by the First Conference in March 1958 when he declared that opposition groups were under his control (Kim 1995). In this paper, the latter was chosen.
} 
the case of the Kim Jong-il era, we made a dummy variable from Kim Il-sung's death in July 1994 through the 'Ruling with the Will' era to the time when Kim Jong-il became chairman of the National Defense Commission in September 1998. For the current leader, the regime-building period was from Kim Jong-il's death in December 2011 to July 2012 when Kim Jong-un was named premier of the Democratic People's Republic of Korea (North Korea's official name).

The dummy variable for the Purge Period was also coded for the domestic factors, which was based on data produced by Kim Jun-dong (2013) for the Kim Il-sung and Kim Jong-il eras and data by Baek Seung-Gu (2015) for the Kim Jong-un era. In addition to the Purge Period, the tendency of the NK leadership to take actions that helped to erase the memory of purged officers may be related to military provocations (Chosun news press 2015). For this reason, we also made an After Purge variable to capture events for three months after purges.

The third variable addressing internal factors, North Korea's GDP per capita, was chosen to reflect the DPRK's economic situation. It is a daunting task to find credible data on North Korea's GDP because of the inherent opacity of its planned economy. Moreover, since the 1970s, North Korea has not announced any official statistics. Fortunately, North Korea's GDP data has been estimated by Kim Byeongyeon (2014), who is an authority in the field of North Korea's national income and economic growth. ${ }^{4}$ The last two internal variables are Nuclear Tests and Missile Tests. ${ }^{5}$ These variables will be used for capturing whether North Korea had the intention to (de)escalate any tension that had arisen through nuclear and missile tests.

As for external factors, the ROK-US Combined Exercise periods were included. The objective of ROK-US training is to deter a NK invasion and to decimate their military capability through the deployment of US military forces to the Korean Peninsula if or when deterrence fails. During the combined training, a significant number of US forces are usually deployed to the Korean Peninsula where the combat readiness of the allies is very high. There is a perception that since the NK leadership tends to avoid military confrontations with the United States, that it should be less provocative during these periods. This data related to ROK-US military exercises were collected from several sources (MND 1994; 2002; 2013).

In addition, US Forces in Korea (USFK) Reduction, SK Elections (presidential

\footnotetext{
${ }^{4}$ Unfortunately, monthly GDP data was not available, so lagged yearly values were used for entire months of the following year.

${ }^{5}$ Someone may raise a query about why these variables are independent variables rather than dependent variables. This question seems reasonable if the research was designed to find the factors that affected missile launches and nuclear tests; however, this research was focused on the local provocations that excluded these events.
} 
and National Assembly) and the Cold-War Period were added for the external factors, as well as the inclusion of the political party of the US president. During the period of the reduction of US forces, North Korea is expected to keep its posture less aggressive because it wants to reduce the presence of USFK on the peninsula. NK military provocations may prompt US and SK leaders to rethink the necessity of US forces, which is what North Korea would like to avoid. Summary statistics of all of the variables are shown in Table 1.

Table 1. Summary Statistics of Variables

\begin{tabular}{c|c|c|c|c|c}
\hline Type & Obs & Mean & Std. Dev. & Min & Max \\
\hline Provocations Dummy & 750 & .4813333 & .499849 & 0 & 1 \\
Provocations Real & 750 & 1.477333 & 3.198196 & 0 & 31 \\
Regime-Building Period & 750 & .152 & .3592605 & 0 & 1 \\
Purge & 750 & .36 & .1864144 & 0 & 1 \\
After Purge & 750 & .0866667 & .2815337 & 0 & 1 \\
GDP Per Capita & 743 & 833.6027 & 126.7637 & 627.8 & 1093.4 \\
Nuclear Crisis & 750 & .153333 & .360549 & 0 & 1 \\
Missile Test & 750 & .036667 & .172528 & 0 & 1 \\
Combined Exercise & 750 & .152 & .3592605 & 0 & 1 \\
USFK Reduction & 750 & .1333333 & .3401615 & 0 & 1 \\
Presidential Election (SK) & 750 & .0413333 & .1991929 & 0 & 1 \\
General Election (SK) & 750 & .04 & .1960899 & 0 & 1 \\
Cold War & 750 & .616 & .4866825 & 0 & 1 \\
Party of US President & 750 & .569333 & .4955 & 0 & 1 \\
Party of SK President & 750 & .796 & .4032379 & 0 & 1 \\
\hline
\end{tabular}

\section{ANALYSIS}

Based on the aforementioned contents, we introduced three models: internal, external, and both variables. The results are in Table 2. Roughly speaking, when domestic or foreign factors were considered separately, the RegimeBuilding Period, After Purge and GDP Per Capita from internal variables, and USFK Reduction and the Cold War Period from the external side, each had a statistically significant relationship with the occurrence of military provocations. Considering both internal and external factors, all the results except GDP Per 
Capita indicate the same results.

Table 2. Domestic and International Factors for North Korea's Military Provocations

\begin{tabular}{|c|c|c|c|}
\hline & \multicolumn{3}{|c|}{ Coefficients } \\
\hline & $\begin{array}{l}\text { Model I } \\
\text { (Internal) }\end{array}$ & $\begin{array}{c}\text { Model II } \\
\text { (External) }\end{array}$ & $\begin{array}{c}\text { Model III } \\
\text { (Both) }\end{array}$ \\
\hline Regime-Building Period & $\begin{array}{c}-1.21^{* * *} \\
(.27)\end{array}$ & & $\begin{array}{c}-1.11^{\text {*** }} \\
(0.28)\end{array}$ \\
\hline Purge & $\begin{array}{c}0.13 \\
(0.42)\end{array}$ & & $\begin{array}{c}0.12 \\
(0.29)\end{array}$ \\
\hline After Purge & $\begin{array}{c}0.90^{* * *} \\
(0.28)\end{array}$ & & $\begin{array}{c}0.92^{* * *} \\
(0.29)\end{array}$ \\
\hline GDP Per Capita & $\begin{array}{c}-0.003^{* * *} \\
(0.0007)\end{array}$ & & $\begin{array}{l}-0.001 \\
(0.001)\end{array}$ \\
\hline Nuclear Tests & $\begin{array}{c}0.27 \\
(0.32)\end{array}$ & & $\begin{array}{l}-0.09 \\
(0.33)\end{array}$ \\
\hline Missile Tests & $\begin{array}{c}0.63 \\
(0.43)\end{array}$ & & $\begin{array}{c}0.39 \\
(0.43)\end{array}$ \\
\hline ROK-US Combined Exercise & & $\begin{array}{l}-0.41 \\
(0.68)\end{array}$ & $\begin{array}{l}-0.14 \\
(0.25)\end{array}$ \\
\hline USFK Reduction & & $\begin{array}{c}-0.48^{* *} \\
(0.22)\end{array}$ & $\begin{array}{l}-0.42^{*} \\
(0.23)\end{array}$ \\
\hline Presidential Election (SK) & & $\begin{array}{c}0.26 \\
(0.38)\end{array}$ & $\begin{array}{c}0.26 \\
(0.40)\end{array}$ \\
\hline General Election (SK) & & $\begin{array}{c}0.15 \\
(0.42)\end{array}$ & $\begin{array}{c}0.04 \\
(0.40)\end{array}$ \\
\hline Cold War Period & & $\begin{array}{c}-1.19^{* * *} \\
(0.19)\end{array}$ & $\begin{array}{c}-1.10^{* * *} \\
(0.25)\end{array}$ \\
\hline Party of US President & & $\begin{array}{c}0.24 \\
(0.17)\end{array}$ & $\begin{array}{c}0.28 \\
(0.18)\end{array}$ \\
\hline Party of SK President & & $\begin{array}{c}0.06 \\
(0.22)\end{array}$ & $\begin{array}{c}0.26 \\
(0.24)\end{array}$ \\
\hline Constant & $\begin{array}{l}1.72^{* * *} \\
(0.39)\end{array}$ & $\begin{array}{c}0.54^{* * *} \\
(0.20)\end{array}$ & $\begin{array}{l}1.61^{* *} \\
(0.77)\end{array}$ \\
\hline $\mathbf{N}$ & 743 & 750 & 743 \\
\hline Pseudo R2 & 0.0501 & 0.0534 & 0.0756 \\
\hline
\end{tabular}

${ }^{*}<0.1,{ }^{* *} p<0.05,{ }^{* * *} p<0.001$. Robust standard errors are in parentheses

\section{INTERNAL FACTORS}

Among the quantitative results for Model-I, which were designed to estimate the effects of internal variables, surprisingly, the possibility of NK provocations were proven to be low during the regime-building period for each newly ascendant leader. This result is not consistent with the argument that during periods 
of regime instability, a leader has the incentive to divert domestic unrest by undertaking the use of force (Levy 1989; Jung 2013). During the period when the former leader passed away until his successor assumed an important title, the outcome of this model demonstrated that the new leadership tended to be less provocative in order not to entangle itself in other problems. Another politically unstable period that was tested was purge periods, in which there was no systematic relationship during the time when the purges actually happened, but there was a positively significant correlation with provocations within the three months after the purges.

Why do the results contradict the arguments offered by a number of other researchers? If we look at this from the perspective of diversionary war theory, obviously provocations must appear highly likely to take place during the regime-building period. However, it was more likely that the possibility of domestic instability caused leaders to consider different policy options. Because all provocations are not always successful all of the time, when they fail, adverse effects could cause challenges to the regime's newly-developed status. In other words, the utility of the use of force could invite a negative impact upon the leader's domestic political position. Considering these risks, other options such as internal repression or reform might have been more attractive to leaders than those suggested by diversionary war theory. Combing these two results, a tentative conclusion may be that North Korea's leaders seemed to use military provocations when they felt politically strong. During the regime-building and purge periods, the existence of military provocations was significantly smaller than anticipated.

On the other hand, the outcome related to the economic condition observed was as expected. GDP per capita was negatively related to the possibility of military provocations. From this, we can say that if North Korea recognized the economy was in crisis, provocations could take place more often for the purposes of diverting the people's focus away from economic problems. However, this does not appear statistically significant in Model III, which includes both internal and external factors. The authors believe that the economic effect is offset by other international factors, such as USFK reductions. It can be said that economic crises have limited effects on the cause of North Korea's local provocations when considering only the internal factors.

Lastly, in the case of nuclear tests and long-range ballistic missile launches, the model does not show a statistically significant relationship with North Korea's provocations. These results can be interpreted as North Korea not having the intention to escalate an intense situation by mixing or adding in an additional crisis. This outcome reinforces argument offered by Yoo (2014) that the utility 
of military provocations tends to be shaped by the combination of other factors. It can be summarily concluded that North Korea usually commits military provocations when the leadership is politically strong and the economy is weak, when considering only domestic factors. During the regime-building period and purging of high-ranking officials, the NK leadership feels politically insecure and so the utility of local provocations is diminished.

\section{EXTERNAL FACTORS}

Three outcomes should be mentioned. First, the possibility of provocations during the ROK-US combined exercise period does not show any statistical significance. This result does not change when we add either 'Before Exercise' or 'After Exercise.' There may be an expectation that North Korea tends to be cautious when US forces have been deployed to the Korean Peninsula. However, in terms of this analysis, this is no longer a valid argument. North Korea does not show any regularity regarding military provocations and the before-duringafter timeframe of ROK-US combined exercises. Furthermore, North Korea may not consider the ROK-US exercises as serious, but rather accepts them as a longterm constant. North Korea utilizes the exercises as a regime threat in terms of domestic propaganda, but there are no systematic changes in the leadership's behaviors as represented by military provocations.

Second, according to the statistical results, the effect of USFK reduction shows that the possibility of provocations was low during periods of force reductions. Since the reduction of USFK gives an advantage to North Korea, there is less incentive for North Korea to invite any trouble that may cause the United States to reconsider such force reductions. Though there was no observable case where North Korea changed provocation plans owing to this reason, there was an example that supported this interpretation. In the 1970s, USFK were reduced by the Carter administration. Based on a statement of the USFK reduction plans, withdrawal would be stopped if any contingency occurred on the Korean Peninsula. As a result, it seems as though North Korea restrained from local provocations on purpose so as not to cause any incident that could escalate into a contingency situation. The outcome produced by this model, wherein the frequency of military provocations was statistically smaller than expected, tells us that the NK leadership sought to be cautious so as not to cause any problems with USFK reductions.

The third external variable deals with the Cold War. Compared to the postCold War period, there were significantly fewer provocations observed during the Cold War period. The collapse of the Soviet Union has invited a more aggressive NK posture because the disappearance of Soviet guardianship made 
North Korea apparently feel less secure. Namely, North Korea had to show that it was strong enough to defend itself to both domestic and international audiences.

\section{CONCLUSION}

This study analyzes the tendencies of NK provocations using a quantitative approach by collecting data and running a statistical model. According to the results, one possible conclusion is that North Korea has a tendency to commit more provocations when the NK leadership feels politically strong or economically weak when only domestic factors are considered in isolation. When regime survival was under threat, such as during leadership transition and purge periods, North Korea was less likely to engage in military provocations. However, it may be possible to observe more cases during times of poor economic conditions.

These also can be interpreted such that the actions of the NK leadership are driven by internal factors rather than external considerations. ${ }^{6}$ An important takeaway from this research is that external efforts and international attempts to change the NK regime's behavior may not be helpful unless these do not produce domestic changes. Therefore, we need to find some means to invite internal change in order to induce changes in NK behavior. Making the NK leadership believe it faces a politically insecure environment internally while keeping economic conditions stable was the most productive policy option gleaned from this research.

In order to produce internal change, a dual track attempt to focus on both the leadership and ordinary people at the same time is needed. The former may have faced obstacles when it comes to implementation but the latter is one possible way to induce NK behavioral change. Keeping ordinary people informed about what is going on externally by disseminating more information and materials directly to NK citizens, while giving the current NK leadership opportunities to participate in international events may be a possible way to promote North Korea to change in cooperative ways.

Lastly, though the general pattern of provocations may not indicate specific times or motivators, this research suggests that the most dangerous time for possible NK military provocations is right after purging high-ranking political

\footnotetext{
${ }^{6}$ Though the reduction of USFK and the Cold War variables have shown significant outcomes, both factors can be directly related to North Korea's domestic conditions compared to other external variables.
} 
officials. The recent assassination of Kim Jong-nam, the half-brother of current leader Kim Jong-un, will likely be followed by another provocation with which the leader will aim to show his secured status.

\section{REFERENCES}

Baek, Seung-Gu. 2015. "Reign of Terror of Dictator Kim Jung-Un's Power Group." Monthly Chosun 15(7). Accessed at http://Monthly.Chosun.com (April 7, 2017).

Chosun News press. "NK's Kim Jung-un Regime, How Weak?" Accessed at http://pub.chosun.com/client/news/print. asp?cate $=$ Co1\&mcate $=\&$ nNewsNumb $=20150717743($ May 17, 2016).

Cha, Victor, Na Young Lee, and Andy Lim. "DPRK Provocations and US-ROK Military Exercises, 2005 to 2016," CSIS Beyond Parallel. Accessed at http://beyondparallel.csis.org/dprk-provocations/ (December 4, 2016).

Gent, Stephen E. 2009. "Scapegoating Strategically: Reselection, Strategic Interaction, and the Diversionary Theory of War." International Interaction 35(1), 1-33.

Han, Kwan-Soo. 2012. "Analysis and Outlook of North Korean Strategic Intentions and Provocations Against South Korea in the Post-Cold War Era." The Journal of Strategic Studies 54(March), 33-64.

Levy, Jack S. 1989. “The Diversionary Theory of War: A Critique.” In Manus I. Midlarsky ed., Handbook of War Studies. Boston: Unwin Hyman, 259288.

Jung, Sung-Chul. 2013. "Diversionary Theory of War: Logic and Evidence." Korean Journal of International Relations 47(5), 389-405.

Kang, Chang-Kook. 2010. "North Korea's Terrorism and Provocations after the Korean War against the ROK and Its Countermeasures.” Military History 75, 295-330.

Gause, Ken E. 2015. "North Korea's Provocation and Escalation Calculus: Dealing with the Kim Jong-un Regime." Center for Strategic Studies, CNA Analysis \& Solution.

Kim, Byung-Yeon. 2014. "Assessing the Economic Performance of North Korea." Understanding of North Korean Economy using Statistics. Economic Research Institute, Bank of Korea.

Kim, Jin-Ha. 2014. "Kim Jung-eun Regim's South Korea Policy: Strategic Origins and the Intensified Cycle of Provocations." Journal of National Defense Studies 57(1), 27-59. 
Kim, Jun-Dong. 2013. "Purges in the Military and Party-Military Relations in North Korea.” Master's Thesis, Kyung-Nam University of North Korean Studies.

Kim, Kook-Shin. 2001. "US Policy to North Korea and NK's Responses." Korea Institute for National Unification (KINU) Research Series. KINU.

Kim, Young-Joon and Jee Hyo-Keun. 2013. "A Study on the Cause of North Korea's Provocations in 1960s and 1970s." Military History Study 136, 277-296.

JoongAng Daily. "Ministry of National Defense, start anti-Pyongyang message broadcasts through speakers for the first time in 11 years, reply about land mining provocation." Accessed at http://news.joins.com/ article/18424239 (Apr 1, 2016).

Ministry of National Defense. 2013. 60 years of the ROK-US Alliance. Institute for Military History Compilation, MND. . 2002. ROK-US Military History 1871-2002. Institute for Military History Compilation, MND.

. 1993. A Chronological Table of Korean Military History 1945-90. Institute for Military History Compilation, MND.

Moon, Soon-Bo. 2012. "North Korea's provocations environmental comparison: Focusing on the major events of 1968 and 2010.” Sejong Policy Studies 13.

. 2011. "Attack on the ROK's Cheonan, Bombardment of Yeonpyeong Island: Causes and Lessons." Proceeding of 2011 The Korean Association of International Studies(KAIS) Security and National Defense Academic Conference(August 26-27).

Republic of Korea Joint Chiefs of Staffs. 2014. Military Terminology Dictionary for Combine and Joint Operations. ROK JCS.

Soon, In-soo. 2012. "The Analysis of Factors Affecting Policy toward North Korea: Comparative Analysis between Lee and Kim Administrations." Master's Thesis, Kyung-Gi University.

Yoo, Sang-Beom. 2014. "The Trend of North Korean Local Military Provocations and Alliance Cooperation.” Journal of National Defense Studies 57(1), 61-80. 